\title{
Understanding creation science and intelligent design
}

\author{
Review of Huskinson, B. 2020. American Creationism, Creation Science, and Intelligent \\ Design in the Evangelical Market. Palgrave Macmillan, Cham (Switzerland)
}

Glenn Branch* ${ }^{*}$

\begin{abstract}
In American Creationism, Creation Science, and Intelligent Design in the Evangelical Market, Benjamin Huskinson presents a close examination of the two main American sociopolitical movements launched in opposition to evolution during the second half of the twentieth century: creation science and intelligent design. Despite a failure of a central argument and a handful of errors, the book is a welcome and valuable interrogation of the stereotypes of American creationism.
\end{abstract}

Keywords: Creationism, Creation science, Intelligent design

Benjamin Huskinson's book, apparently based on his 2018 dissertation at Queen's University Belfast, presents a close examination of the two main American sociopolitical movements launched in opposition to evolution during the second half of the twentieth century: creation science and intelligent design. "Creation science was developed as a response to perceived threats to evangelical orthodoxy" (p. 108), he emphasizes, not as a rival position to balance the teaching of evolution in the public schools-although it was so advanced in short order. In contrast, intelligent design was concocted as a supposedly scientific alternative to evolution, but in the wake of the Kitzmiller $v$. Dover decision of 2005, which dashed its political ambitions, its proponents now often seem to be flailing about in the hope of finding a social function to perform.

Correspondingly, Huskinson also argues convincingly that the career of American creationism was, and continues to be, shaped by competition (as well as cooperation) among creationist organizations for the authority to perform the social functions demanded of creationism. In a

*Correspondence: branch@ncse.ngo

National Center for Science Education, 230 Grand Avenue, Suite 101,

Oakland, CA 94610, USA particularly piquant discussion, he examines the federal tax returns for 1997-2015 of the largest creation science organizations, concluding that the Institute for Creation Research and Answers in Genesis are growing at the expense of their smaller rivals, with the latter, newer, organization experiencing the most growth, thanks to its multimillion-dollar tourist attractions. Owing to increasing secularization and education, adverse judicial decisions, and the rise of the internet, however, he suspects that anti-evolutionism is on the wane.

There is still plenty of anti-evolutionism around, and evolution educators are often on the receiving end of its political ambitions. In a 2019 national survey (discussed in Plutzer et al. 2020), about one in seven public high school biology teachers reported experiencing pressure to teach creationism, while in 2021, a bill to allow public school science teachers to present creationism passed the Arkansas House of Representatives before dying in committee (Brantley 2021). Yet it would be helpful for evolution educators to understand Huskinson's distinction between political ambitions and social functions in order to appreciate that not all creationists are bent on undermining the integrity of public science education-although the 
message is conveyed more adroitly by Adam Laats in his recent Creationism USA (2021).

A fair amount of American Creationism, Creation Science, and Intelligent Design in the Evangelical Market usefully summarizes and synthesizes previous literature about antievolutionism in the United States, so it is convenient that Huskinson explicitly lists what he takes to be his original contributions to the topic. Of these, the most interesting is "that [intelligent design] does not perform the same function as American creationism, and is not a repackaged form of creationism" (p. 35). Indeed, in his endorsement of the book, the historian of religion Randall Balmer (who cowrote and hosted the 1995 documentary In the Beginning: The Creationist Controversy) writes that he was prompted by Huskinson to rethink his conviction that intelligent design "is merely the most recent evolutionary form of creationism."

Unfortunately, however, nowhere in the book is there a cogent argument that intelligent design is anything but the most recent evolutionary form of creationism. In fact, Huskinson concedes that, given a broad definition of creationism that might be suitable in philosophy or the history of ideas, there is no obstacle to describing intelligent design as at least "of 'creationist' origin" (p. 76) or even as creationism tout court (p. 138). Why, then, insist on a narrower definition that excludes intelligent design? His main argument, presented repeatedly with variations, cites various differences in beliefs, aims, strategies, tactics, and audiences between intelligent design and creation science (identified, plausibly, with the views of the Institute for Creation Research) as evidence that intelligent design is not creationism.

But the argument is invalid without the implicit premise that creation science and creationism are the same. Since Huskinson elsewhere in the book acknowledges the existence of creationists who do not accept creation science, it is hard to understand why he regards the implicit premise as plausible. Ironically, he complains that the decision in Kitzmiller v. Dover, in which the teaching of intelligent design in the public schools was ruled to be unconstitutional, "used the term 'creationism' as being synonymous with "creation science"' (p. 148). Not so. In fact, the decision explicitly notes that although the defendants so used the term, "substantial evidence" from the philosopher Barbara Forrest on behalf of the plaintiffs "established that [creation science] is only one form of creationism."

The confusion is only exacerbated when Huskinson recommends "American creationism" as a label for "the proximity $[s i c]$ and often overlapping areas of various theological positions with responses to mainstream scientific consensus in the United States"-which, it turns out, would "often" include intelligent design, at least for "its theistic proponents" (p. 108). So is intelligent design more or less creationism as far as he is concerned after all? It is unclear. It is also unclear what is to be gained by adopting such a capacious definition of creationism, which would apply also to so-called theistic evolutionists and thus entail that the political struggles over the teaching of evolution in the United States over the last century have typically involved creationists on both sides.

Huskinson's book is overall well-researched, well-organized, and well-written, although there are ways in which it could have been strengthened. A firmer grasp of the issues involved in defining creationism, a deeper review of the literature (especially as regards the early history of intelligent design that surfaced during preparations for the Kitzmiller trial: Matzke 2009), and a more nuanced treatment of the often complex and shifting goals of creationist organizations would have been helpful. A further round of editing would also have been desirable: there are a handful of awkward typos and simple errors of fact. Nevertheless, American Creationism, Creation Science, and Intelligent Design in the Evangelical Market serves as a welcome and valuable interrogation of the stereotypes of American creationism.

\section{Acknowledgements \\ Thanks to Barbara Forrest for discussion. \\ Authors' contributions \\ Glenn Branch is the sole author of the article. \\ Funding \\ Not applicable.}

Availability of data and materials

Not applicable.

\section{Declarations}

Competing interests

Not applicable.

Received: 8 June 2021 Accepted: 15 July 2021

Published online: 26 July 2021

\section{References}

Brantley M. Credit where due: Democrat minority turns back creationism and cruelty to transgender children in Senate committee. Arkansas Times. 2021 April 22. https://arktimes.com/arkansas-blog/2021/04/22/credit-wheredue-democrat-minority-turns-back-creationism-and-cruelty-to-trans gender-children-in-senate-committee.

Laats A. Creationism USA. bridging the impasse on teaching evolution. New York: Oxford University Press; 2021

Matzke N. But isn't it creationism? The beginnings of "intelligent design" and Of Pandas and People in the midst of the Arkansas and Louisiana litigation. In Pennock RT, Ruse M, editors. But is it science? The philosophical question in the creation/evolution controversy, updated ed. Amherst, NY: Prometheus Books; 2009. p. 377-413.

Plutzer E, Branch G, Reid A. Teaching evolution in U.S. public schools: a continuing challenge. Evol Edu Outreach. 2020;13:14.

\section{Publisher's Note}

Springer Nature remains neutral with regard to jurisdictional claims in published maps and institutional affiliations. 